\title{
14. COARSE FRACTION MINERALOGY OF LEG 43 SEDIMENTS
}

\author{
Ivar O. Murdmaa, V. Kazakova, and A. Rudakova, P. P. Shirshov Institute of Oceanology, \\ USSR Academy of Sciences, Moscow, USSR
}

\section{INTRODUCTION}

The main objective of this investigation was to distinguish characteristic heavy and light mineral assemblages in Leg 43 sediments described as volcanogenic, and to contrast them with land-derived clastic assemblages.

Sediment samples were dispersed and the 50 to 100 $\mu \mathrm{m}$ fraction was separated for mineralogical investigation. Also used were $>62 \mu \mathrm{m}$ residues from routine grain-size analyses carried out at DSDP headquarters at Scripps Institution of Oceanography. The difference in the lower size limits between the two fractions was assumed to be unimportant. Heavy and light fractions were separated in bromoform (specific gravity 2.9 $\left.\mathrm{g} / \mathrm{cm}^{3}\right)$. Three hundred to five hundred grains of each fraction were counted in immersion liquids to calculate the mineral percentages. Relative percentages of transparent heavy minerals were calculated, taking their sum as 100 per cent. This calculation was done only for samples in which the number of transparent mineral grains exceeded 25 (normally, the number was greater than 50). Identification of some minerals was additionally checked by X-ray or qualitative chemical tests (phosphates, for example).

\section{HEAVY MINERALS}

The total composition of heavy mineral fractions is shown on the right side of Table 1. Identified transparent minerals constitute 5 to 89 per cent of the fraction; the remainder are opaques, unidentified and altered grains, mineral aggregates, and rock fragments. The proportion of transparent minerals is rather high in terrigenous turbidites (Site 382, Cores 1-3 and Site 383 ), as well as in those samples of hemipelagic clay (Site 385, Core 1) and marly nannofossil ooze (Site 386 , Core 1) where the amount of coarse material was sufficient to make quantitative determinations. High values in some pelagic sediments and siliceous turbidites are related to the authigenic carbonates-siderite and rhodochrosite.

In sediments described as volcanogenic or volcaniclastic at Sites 382, 385, and 386, the proportion of transparent minerals is highly variable. At Sites 382 and 385 it ranges from five to as much as 89 per cent. Relatively high values characterize the volcaniclastic turbidite sequence at Site 386.

The composition of the opaque fraction shows essential variations. Magnetite (titanomagnetite?) is common in volcanogenic sediments, whereas in terrigenous sediments authigenic pyrite and other non-magnetic minerals predominate among the opaque grains.

Twenty-two transparent heavy minerals were determined (Table 1). Most abundant among clastic minerals are hornblende and clinopyroxene, and in some cases epidote and sphene. Authigenic carbonates (siderite and rhodochrosite) constitute almost the whole heavy fraction in some cases, masking relationships between clastic minerals.

The terrigenous mineral assemblage of the PliocenePleistocene turbidites from the Sohm Abyssal Plain (Site 382, Cores 1-3 and Site 383) is dominated by green hornblende, clinopyroxene, and epidote. Other typical minerals are garnet, zircon, apatite, and orthopyroxene. Similar patterns appear in hemipelagic sediments of the uppermost lithologic units of Sites 385 and 386.

Quite different mineral assemblages typify the volcanogenic sediments. Moreover, the mineralogy of volcaniclastics from the New England Seamounts (Sites 382 and 385) differs from that of the Bermuda Rise volcaniclastic turbidites of Site 386 . The most important mineral in the Site 382 volcaniclastics is hornblende, usually including considerable portions of oxidized reddish brown basaltic hornblende. In the upper part of the volcanogenic sequence (Core 16) it is associated with unusually high percentages of sphene (24\% to 49\%); in the lower part (Core 17, Section 6 to Core 22) it is associated with clinopyroxene and minor sphene. Apatite is present in most samples, and high values appear in the lower part of the sequence. It is noteworthy that epidote was found in most samples together with sphene, suggesting low-grade metamorphism of the volcaniclastic material. Such terrigenous minerals as garnet, orthopyroxene and tourmaline are virtually absent, but zircon of unknown origin was found in several samples. Iron-rich altered palagonite is abundant in Core 16, Site 382, and in Cores 16 and 19 at Site 385.

On the Bermuda Rise, in contrast, clinopyroxene, including some aegirine, is dominant in the volcaniclastic turbidites at Site 386. Chrome spinel and apatite are common, together with minor hornblende, epidote, sphene, and anatase. Garnet, barite and zircon appear sporadically. The clinopyroxene and spinel association seems to be indicative of a specific volcaniclastic source rock, most likely alkali basalt. Sphene, anatase, epidote, and garnet may be interpreted as pre-depositional alteration products of volcaniclastic material. Barite and some of the apatite are probably authigenic. Origin of the zircon is uncertain. 
TABLE 1

Coarse Fraction Mineralogy - Heavy Minerals

\begin{tabular}{|c|c|c|c|c|c|c|c|c|c|c|c|c|c|c|c|c|c|c|c|c|c|c|c|c|c|c|c|c|c|}
\hline \multirow{3}{*}{$\begin{array}{c}\text { Sample } \\
\text { (Interval in cm) }\end{array}$} & \multicolumn{22}{|c|}{ Transparent Minerals } & \multicolumn{7}{|c|}{ Total Composition } \\
\hline & \multirow[b]{2}{*}{ Gr } & \multirow[b]{2}{*}{$\mathrm{Hb}$} & \multirow[b]{2}{*}{$\mathrm{Ac}$} & \multirow[b]{2}{*}{ Pxr } & \multirow[b]{2}{*}{$\mathrm{Pxm}$} & \multirow[b]{2}{*}{ Ep } & \multirow[b]{2}{*}{ Tn } & \multirow[b]{2}{*}{ Sph } & \multirow[b]{2}{*}{ St } & \multirow[b]{2}{*}{$\mathrm{Chl}$} & \multirow[b]{2}{*}{ Bi } & \multirow[b]{2}{*}{$\mathrm{Spl}$} & & & & & $\begin{array}{l}\text { Rhd } \\
+\end{array}$ & & & & & & & Opaqu & & & & & \\
\hline & & & & & & & & & & & & & $Z_{\mathrm{rk}}$ & Ap & $\mathrm{Ru}$ & Ant & Sid & Sil & Ky & Bar & Mon & Pal & Mgt & Pyr & I. $o x$ & Leu & oth. & un & tr \\
\hline e 382 & & & & & & & & & & & & & & & & & & & & & & & & & & & & & \\
\hline $1-2,60-62$ & 12 & 20 & 2 & 7 & 20 & 15 & 1 & 1 & 4 & 1 & - & - & 4 & 2 & 1 & - & 7 & 1 & + & 1 & - & - & 3 & & 1 & 2 & & & \\
\hline & $\begin{array}{l}9 \\
0\end{array}$ & 18 & 2 & 5 & 19 & 12 & 2 & 1 & 3 & - & - & + & 4 & $i$ & 2 & - & 17 & 2 & - & 1 & - & & & 14 & + & 1 & 27 & 7 & 51 \\
\hline & 0 & 33 & 5 & 2 & 5 & 28 & & & & - & - & 2 & 10 & - & 2 & - & 10 & -1 & - & & - & - & 5 & 45 & 1 & $x^{\circ}$ & 22 & - & 27 \\
\hline & 6 & 29 & 2 & 10 & 11 & 16 & - & 2 & 1 & - & - & - & 1 & 2 & 6 & - & 16 & - & - & + & - & - & - & 1 & 5 & 3 & 10 & 3 & 78 \\
\hline & 99 & 26 & 3 & 21 & 8 & 16 & 4 & - & 1 & 1 & 1 & - & 1 & 1 & - & - & 2 & 2 & - & 2 & - & - & 5 & 40 & 8 & - & 8 & 9 & 30 \\
\hline & 4 & 35 & - & 11 & 11 & 13 & - & + & 1 & - & t & - & + & 2 & 1 & - & 19 & + & - & 1 & - & - & - & 6 & 4 & 2 & 24 & 10 & 54 \\
\hline & $\begin{array}{l}6 \\
9\end{array}$ & $\begin{array}{l}34 \\
36\end{array}$ & 2 & $\begin{array}{r}7 \\
10\end{array}$ & $\begin{array}{l}8 \\
8\end{array}$ & $\begin{array}{l}7 \\
5\end{array}$ & - & $\overline{1}$ & - & + & - & - & 3 & 4 & + & - & 26 & - & - & 1 & - & - & 1 & 9 & 3 & + & 18 & 11 & 58 \\
\hline & $\begin{array}{l}9 \\
8\end{array}$ & $\begin{array}{l}36 \\
24\end{array}$ & - & $\begin{array}{r}10 \\
8\end{array}$ & $\begin{array}{r}8 \\
10\end{array}$ & $\begin{array}{r}5 \\
16\end{array}$ & - & $\begin{array}{l}1 \\
3\end{array}$ & $=$ & - & & $-\overline{3}$ & $\begin{array}{l}3 \\
3\end{array}$ & + & - & - & $\begin{array}{l}24 \\
26\end{array}$ & $\stackrel{+}{+}$ & - & 2 & - & - & - & 4 & 2 & 3 & $\begin{array}{l}35 \\
29\end{array}$ & $\begin{array}{l}7 \\
8\end{array}$ & 49 \\
\hline 3 & 1 & 9 & 1 & $\begin{array}{l}8 \\
2\end{array}$ & $\begin{array}{r}10 \\
2\end{array}$ & $\begin{array}{l}10 \\
14\end{array}$ & 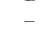 & -3 & $=$ & - & $\overline{1}$ & 3 & $\begin{array}{l}3 \\
+\end{array}$ & - & - & - & $\begin{array}{l}26 \\
68\end{array}$ & & - & -2 & - & $\overline{-}$ & - & $\begin{array}{r}10 \\
8\end{array}$ & + & 1 & $\begin{array}{r}29 \\
9\end{array}$ & $\begin{array}{r}8 \\
10\end{array}$ & 52 \\
\hline 15 & 6 & 3 & & 4 & 64 & 3 & - & - & - & - & - & 8 & 5 & 3 & - & - & - & - & - & 3 & $\overline{-}$ & $\bar{z}$ & - & 8 & $\begin{array}{l}6 \\
5\end{array}$ & 1 & $\begin{array}{r}9 \\
19\end{array}$ & $\begin{array}{l}10 \\
18\end{array}$ & $\begin{array}{l}67 \\
57\end{array}$ \\
\hline & & & - & + & 12 & - & - & - & - & - & - & - & - & - & - & - & - & - & - & 87 & - & - & 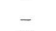 & - & & 1 & & 38 & 62 \\
\hline & - & $23 \mathrm{x}$ & - & 2 & 9 & 1 & - & 46 & - & - & - & 2 & 5 & - & - & - & 1 & - & - & 5 & - & - & 22 & - & 12 & 3 & 42 & 4 & 17 \\
\hline & - & 36 & - & - & 24 & - & - & 36 & - & - & - & - & - & - & - & - & - & - & - & - & 4 & - & 63 & - & 6 & 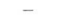 & - & 22 & 9 \\
\hline & - & $\begin{array}{l}76 \\
41\end{array}$ & - & - & - & - & - & $\begin{array}{l}24 \\
49\end{array}$ & - & - & - & - & - & - & - & - & - & - & - & - & - & - & 10 & - & + & - & - & - & 89 \\
\hline & - & $\begin{array}{l}41 \\
18\end{array}$ & $\overline{-}$ & - & $\begin{array}{r}+ \\
46^{+}\end{array}$ & - & - & $\begin{array}{r}49 \\
7\end{array}$ & - & - & $=$ & + & $\overline{4}$ & ${ }_{7}^{2}$ & - & $\overline{-}$ & 7 & - & - & - & + & $\overline{-}$ & & - & $\begin{array}{r}6 \\
6\end{array}$ & 1 & $\overline{13}$ & 5 & 77 \\
\hline & - & 2 & - & - & 46 & - & - & - & 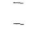 & - & $\bar{z}$ & - & ${ }_{-}^{4}$ & - & - & - & $\bar{z}$ & - & - & ${ }_{-}^{6}$ & - & $\overline{66}$ & & I & 14 & $\frac{1}{-}$ & 13 & $\begin{array}{l}12 \\
11\end{array}$ & $\begin{array}{l}11 \\
14\end{array}$ \\
\hline & 3 & 22 & - & - & 19 & 3 & - & 5 & - & - & - & 3 & 11 & 24 & 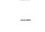 & - & - & - & - & 3 & 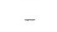 & 6 & J1 & - & 10 & 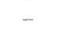 & 14 & 2 & 14 \\
\hline & & 2 & - & - & 19 & & - & 5 & & - & - & - & - & 2 & - & - & - & - & - & - & - & 64 & - & - & & - & 15 & 37 & 48 \\
\hline & - & $19^{\mathrm{x}}$ & & & 8 & 2 & - & 1 & - & - & - & - & 2 & 5 & - & - & 1 & - & - & - & - & 62 & - & - & 22 & - & 51 & 6 & 21 \\
\hline & 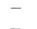 & 1 & - & - & - & - & - & !1 & & - & & & - & - & - & - & 89 & & - & - & - & & 44 & - & 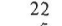 & - & - & - & 34 \\
\hline & - & $43 x$ & - & - & + & - & - & 1 & - & - & - & - & - & 1 & - & - & - & - & - & - & - & 96 & & - & & - & - & - & 73 \\
\hline & - & $\begin{array}{l}43^{x} \\
38^{x}\end{array}$ & - & - & 5 & ${ }_{-}^{2}$ & $\overline{-}$ & $\overline{6}$ & $=$ & - & 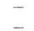 & - & - & 28 & - & - & - & - & - & 23 & - & $\begin{array}{r}4 \\
39\end{array}$ & & - & 8 & - & 32 & - & 33 \\
\hline & 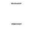 & $\begin{array}{l}3 \\
4\end{array}$ & - & - & $\begin{array}{r}5 \\
17\end{array}$ & $\bar{c}_{6}$ & $\overline{-}$ & $\begin{array}{l}6 \\
6\end{array}$ & 1 & - & 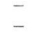 & $\overline{-}$ & $\overline{-}$ & $\begin{array}{r}12 \\
8\end{array}$ & - & - & $\overline{6}$ & $\overline{-}$ & $\Xi$ & -3 & $\overline{6}$ & 39 & 5 & -7 & 11 & $\overline{-}$ & $\overline{-}$ & $\overline{23}$ & $\begin{array}{l}27 \\
10\end{array}$ \\
\hline & . & & - & - & 1 & 3 & & 4 & 1 & - & - & - & - & 11 & - & - & - & - & - & - & - & - & & - & & - & - & 20 & 60 \\
\hline & - & & - & - & 1 & 2 & - & 10 & - & - & & - & & 22 & & - & - & - & - & 4 & & - & 23 & - & 49 & - & - & 17 & 11 \\
\hline & - & 5 & - & - & 2 & 3 & 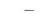 & 6 & 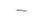 & - & - & - & - & 12 & - & - & - & - & - & - & 2 & - & & - & & - & - & - & 15 \\
\hline & - & 31 & - & - & 4 & 2 & - & 9 & - & - & - & - & 2 & 7 & - & + & - & - & - & - & + & - & & - & & - & - & 6 & \\
\hline & - & $\begin{array}{l}38 \\
34\end{array}$ & - & - & 5 & & - & 4 & & - & & - & $\overline{2}$ & 4 & - & - & - & - & & - & - & $\overline{7}$ & & - & 4 & - & $\bar{\gamma}$ & $\overline{10}$ & 21 \\
\hline & 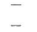 & $\begin{array}{l}34 \\
39\end{array}$ & - & ${ }_{-}^{+}$ & $\begin{array}{l}55 \\
3\end{array}$ & ${ }_{1}^{2}$ & - & ${ }_{+}^{2}$ & & - & & - & $\begin{array}{l}2 \\
+\end{array}$ & $\begin{array}{l}4 \\
2\end{array}$ & & - & - & - & & ${ }_{+}$ & - & $\begin{array}{c}+ \\
20\end{array}$ & & - & & - & $\begin{array}{r}22 \\
4\end{array}$ & 12 & . \\
\hline & 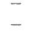 & $\begin{array}{l}3 \\
5\end{array}$ & - & $\overline{-}$ & $\begin{array}{l}35 \\
30\end{array}$ & 1 & - & ${ }_{4}^{+}$ & & 2 & 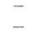 & - & $\stackrel{+}{+}$ & $\begin{array}{l}2 \\
2\end{array}$ & 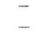 & 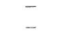 & $\bar{z}$ & - & & ${ }_{4}^{+}$ & $\overline{-}$ & & & - & 3 & $\overline{-}$ & $\begin{array}{r}4 \\
-\end{array}$ & $\begin{array}{r}7 \\
17\end{array}$ & $\begin{array}{l}70 \\
17\end{array}$ \\
\hline & - & 23 & - & - & 8 & 5 & - & 5 & & - & - & - & 3 & 20 & 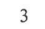 & - & - & - & - & . & - & 33 & & - & 3 & - & - & 18 & 7 \\
\hline & - & 1 & - & - & 7 & 1 & - & - & - & - & - & - & - & - & & - & - & - & - & 14 & - & - & & - & & - & - & 8 & 26 \\
\hline & & $\begin{array}{l}58 \\
63\end{array}$ & & & 10 & 3 & - & 8 & - & - & 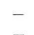 & - & 9 & 9 & - & - & - & - & 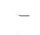 & 1 & - & - & & 3 & & - & - & - & 62 \\
\hline $22-1,122$ & -7 & $\begin{array}{l}63^{x} \\
68^{x}\end{array}$ & -1 & - & $\begin{array}{r}7 \\
14\end{array}$ & $\ldots$ & & 1 & & & & - & - & 10 & - & 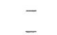 & - & - & & + & - & $\begin{array}{l}6 \\
2\end{array}$ & 73 & - & 1 & $\overline{-}$ & $\begin{array}{l}4 \\
-\end{array}$ & - & 26 \\
\hline & & & & & & & & & & & & & & & & & & & & & & & & & & & & & \\
\hline
\end{tabular}

Site 383

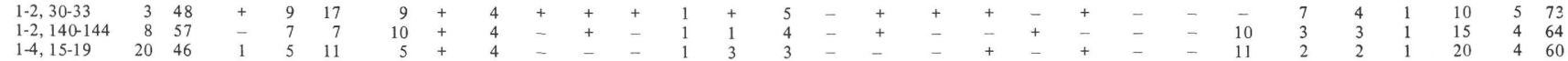
Site 384

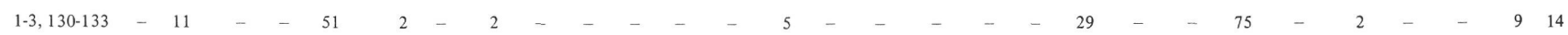
Site 385

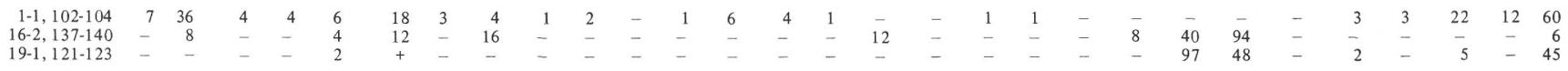

Site 386

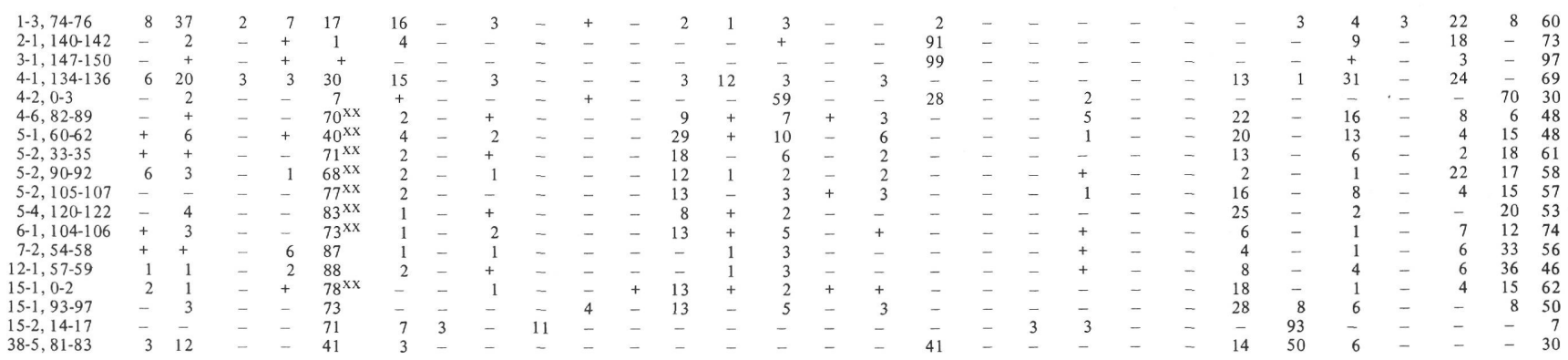

Site 387

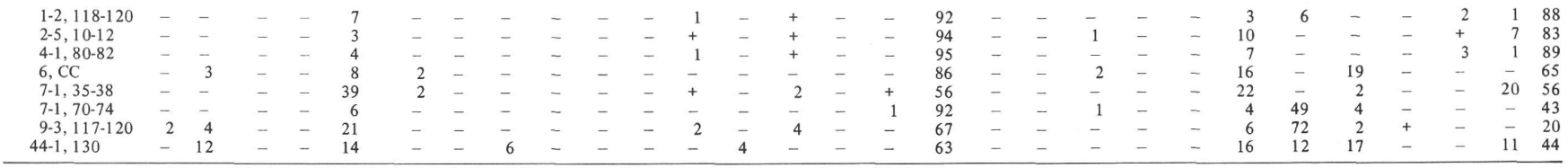

Note: Transparent minerals are summed to 100 per cent. Gr - garnet; $\mathrm{Hb}$ - hornblende; Ac - actinolite + tremolite; Pxr - orthopyroxene; Pxm - clinopyroxene; Ep - epidote group; Tn - tourmaline; Sph sphene; St - staurolite; Chl - chlorite; Bi - biotite; Spl - spinel (mostly chromium); Zrk - zircon; Ap - apatite; Ru - rutile; Ant - anatase; Rhd + Sid - rhodochrosite, siderite; Sil - sillimanite; Ky kyanite; Bar - barite; Mon - monazite; Pal - palagonite; Mgt - magnetite; Pyr - pyrite; 1 . ox - iron oxides; Leuc - leucoxene; oth. - other opaques; un - unspecified grains altered minerals, rock fragments;
$\mathrm{tr}$ - sum of transparent minerals. $\mathrm{x}$ - abundant basaltic hornblende, $\mathrm{xx}$ - aegirine included, + - traces (less than $1 \%$ ), 0 - not found. 


\section{LIGHT MINERALS}

Light minerals could be determined in more samples than could heavy minerals (Table 2). The light fraction consists of terrigenous, volcanogenic, authigenic, and biogenic particles, each characteristic for certain lithologic types of sediments.

In the Pleistocene turbidites and Miocene hemipelagic clay (Sites 382 and 383) detrital terrigenous minerals are represented by quartz, potassium feldspar, and albite-oligoclase, with low percentages of labradoritic plagioclase, mica, and chlorite. About 10 to 20 per cent is unspecified grains. Quartz to feldspar ratios are virtually constant in the turbidites, ranging from 1.9 to 2.7; they are somewhat more variable in the hemipelagic sediments and biogenic turbidites ( 1.8 to 17.0). Quartz always predominates over feldspar. Glauconite, chlorite, and mica, as well as biogenic calcareous particles (foraminifers), are common minor constituents. Zeolites occur in places.

In the volcaniclastic sediments at Sites 382 and 385 unspecified grains (mostly altered basalt fragments and mineral aggregates), zeolites (phillipsite and clinoptilolite), chlorite-like minerals, and palagonite are the most important constituents. Percentages of each are variable. Rock fragments commonly predominate, comprising up to 90 per cent of the light fraction. High zeolite and palagonite content was found in the volcanogenic variegated clay (Subunit 3A) at Site 382, Cores 16 and 17, whereas palagonite and basaltic glass are abundant at Site 385, Cores 16 and 19. Biogenic carbonates occur in most samples, they constitute up to 70 per cent of the light fraction at Site 382. Biogenic phosphate (bone debris) occurs occasionally. Both chlorite (chlorophaeite?) and zeolites are presumed to be mostly of clastic rather than of authigenic origin, as indicated by the fragmental shape of the grains. Some authigenic zeolites may be present. Feldspar is scarce. This may be interpreted either as a specific feature of primary volcaniclastic material or, more likely, as an indication of alteration of the source rocks before dispersal to the drill sites. Chlorite and zeolites are probably the alteration products. Quartz is scarce or absent, but several samples contain more quartz than feldspar, likely indicating an admixture of terrigenous matter.

The uppermost layers of the volcanogenic sequences at Site 382 (Core 15) and 385 (Cores 14, 15) are markedly different from other volcanogenic sediments. They contain relatively abundant bone debris (up to $54 \%$ ), along with zeolites, biogenic carbonate, and chalcedony. Terrigenous quartz is present, palagonite and volcanic glass are scarce. These layers may thus be interpreted as pelagic rather than volcaniclastic.

In the volcaniclastic turbidites at Site 386 (Core 4 through 12) altered basalt fragments, mineral aggregates, and chlorite predominate along with biogenic carbonates. Quartz and feldspar are rare or absent, and zeolites are common.

A nearly pure zeolite concentrate was found in pelagic sediments at Site 385 , Cores 8 to 12 , where zeolites comprise 85 to 96 per cent, and are associated with minor organogenic carbonate and bone debris. In the Eocene radiolarian muds and oozes at Sites 386 and 387 biogenic siliceous material predominates.

\section{DISCUSSION}

The following characteristic coarse fraction mineral assemblages were distinguished in Leg 43 sediments; they are indicative of different sedimentary facies and provenance:

1) A terrigenous assemblage, best developed in the Pleistocene-Pliocene turbidites of the Sohm Abyssal Plain and in the Miocene hemipelagic clay at Sites 382, 383 , and 385 , but represented also in Pleistocene marly nannofossil ooze at Site 386 . Heavy minerals are characterized by a hornblende-clinopyroxene-orthopyroxene-epidote association with garnet, zircon, apatite, and several other accessories common in metamorphic rocks. Quartz predominates in the light fraction; however, acidic feldspars are relatively abundant and the quartz to feldspar ratios are much less than in typical quartzose sand. Concentrations of the most stable heavy minerals are rather low; thus, differentiation during weathering and reworking was not extensive. A typical continental source area with moderately weathered metamorphic rocks (schists, amphibolites, gneisses, and granites) may be assumed.

2) Assemblages of altered basaltic volcaniclastics, as represented in three volcanogenic sequences drilled during Leg 43 (Sites 382, 385, 386). Each of the three show as a common feature alteration of the primary volcaniclastic material and very low feldspar content. The feldspars, where present, are mostly acidic ( $\mathrm{K}$ feldspar and albite). Unaltered volcanic glass was found only in a few samples at Site 385; most of the primary glassy material is completely altered to palagonite, chlorophaeite(?), chlorite, zeolites, and other alteration products.

Two heavy mineral assemblages were distinguished within the volcanigenic sequences:

(a) that of New England seamounts (Sites 382 and 385 ) represented by hornblende and clinopyroxene as primary volcaniclastic minerals, in association with abundant sphene, common epidote, apatite, and barite which is probably not a primary volcanic constituent;

(b) that of Bermuda Rise (Site 386), characterized by clinopyroxene and chrome spinel, in association with apatite, epidote, hornblende, sphene, occasional garnet, anatase, zircon, and barite.

It is apparent that in both cases metamorphic minerals are involved, indicating that the primary volcaniclastic material had already been altered before it was carried downslope by gravity transport and deposited as volcaniclastic sediment. The clastic appearance of the minerals (except for barite and partially apatite and zeolite) testifies against their authigenic origin. It is assumed, therefore, that mineral assemblages in the volcaniclastic sequences were not directly derived from volcanic eruptions, but may be the products of destruction and reworking of altered (weathered, metamor- 
TABLE 2

Coarse Fraction Mineralogy - Light Minerals (\% of counted grains)

\begin{tabular}{|c|c|c|c|c|c|c|c|c|c|c|c|c|c|c|c|c|c|c|}
\hline $\begin{array}{c}\text { Sample } \\
\text { (Interval in } \mathrm{cm} \text { ) }\end{array}$ & Qz & $\mathrm{Fs}$ & $\mathrm{Pl}$ & $\mathrm{Mc}$ & V.a. & V.b. & Pal & Chl & $\mathrm{Ze}$ & $\mathrm{Gl}$ & Che & Gy & C.u. & C.o. & S.o. & P.o. & Un & $\begin{array}{l}\mathrm{Qz} \\
\mathrm{Fis}\end{array}$ \\
\hline \multicolumn{19}{|l|}{ Site 382} \\
\hline $1-2,60-62$ & 42 & 16 & + & 1 & _- & _- & - & 1 & _- & 11 & 1 & - & - & 12 & - & _- & 16 & 2.6 \\
\hline $1-3,126-128$ & 51 & 18 & 1 & + & - & - & - & + & - & 12 & - & - & - & 7 & - & - & 10 & 2.7 \\
\hline $1-4,9$ & 40 & 20 & - & 1 & - & - & - & 1 & - & - & - & - & - & 17 & - & - & 18 & 2.0 \\
\hline $1-6,40-42$ & 46 & 23 & + & - & - & - & - & 1 & - & 2 & - & - & - & 17 & - & - & 12 & 2.0 \\
\hline $2-1,60-70$ & 48 & 18 & + & - & - & - & - & 1 & - & 5 & - & - & - & 7 & + & - & 20 & 2.7 \\
\hline $2-3,4$ & 48 & 23 & 1 & - & - & - & - & 1 & - & 5 & - & - & - & 6 & - & - & 17 & 2.0 \\
\hline $2-3,6$ & 52 & 18 & 1 & + & - & - & - & - & + & 5 & - & - & - & 6 & - & - & 18 & 2.7 \\
\hline $2-3,92-94$ & 49 & 23 & - & - & - & - & - & + & - & 4 & 1 & - & - & 4 & - & - & 17 & 2.1 \\
\hline $3-2,100-102$ & 54 & 20 & 1 & - & - & - & - & - & - & 2 & - & - & - & 7 & - & - & 18 & 2.6 \\
\hline $3-2,147-149$ & 46 & 20 & - & - & - & - & - & 1 & + & 8 & 3 & - & - & 6 & - & - & & 2.3 \\
\hline $5-3,100-102$ & 50 & 22 & - & 2 & + & - & - & 1 & 1 & 2 & - & - & - & 4 & + & 3 & 14 & 2.3 \\
\hline $6-2,148-150$ & 55 & 20 & + & 1 & - & - & - & 1 & - & - & 1 & - & - & 5 & - & 3 & 13 & 2.8 \\
\hline $7-1,43-45$ & 45 & 25 & 1 & - & 1 & + & - & + & + & 1 & - & - & - & 2 & + & 4 & 17 & 1.8 \\
\hline $7-6,67-69$ & 17 & 7 & - & - & + & - & - & - & - & - & - & - & 60 & - & - & 13 & 17 & 2.4 \\
\hline $8-5,97-99$ & 34 & 9 & - & - & - & - & - & 2 & + & 2 & + & - & 30 & - & - & 15 & 0 & 3.8 \\
\hline $9-1,100-102$ & 50 & 20 & - & - & - & - & - & 2 & - & - & - & - & 4 & 2 & - & 8 & 15 & 2.5 \\
\hline $11-4,76-78$ & 44 & 15 & - & - & + & - & - & 1 & - & & - & - & 1 & - & - & 24 & 16 & 2.3 \\
\hline $12-4,103-105$ & 34 & 2 & - & - & - & - & - & - & + & - & - & - & 1 & 1 & 33 & 25 & 0 & 17.0 \\
\hline $13-1,34-36$ & 13 & 5 & + & - & - & - & - & 2 & - & - & - & - & - & 6 & 15 & 47 & 12 & 2.6 \\
\hline $14-5,123-125$ & 14 & 4 & + & + & 1 & - & - & 3 & 1 & 1 & - & - & 2 & - & 7 & 33 & 33 & 3.4 \\
\hline $15-4,10-12$ & 12 & 3 & + & - & + & - & 1 & 11 & 5 & + & - & - & - & 20 & - & 14 & 33 & 3.1 \\
\hline $6,8-10$ & 4 & 1 & + & 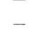 & - & - & ${ }_{-}^{1}$ & 2 & 5 & - & - & - & - & 3 & - & 54 & & 3.2 \\
\hline $16-1,130-134$ & - & 1 & - & - & - & - & + & 2 & 62 & - & - & - & - & - & - & 5 & 30 & 0.2 \\
\hline $16-2,46-49$ & + & 5 & - & - & - & - & 1 & - & 4 & - & - & - & - & 5 & - & - & 85 & 0.1 \\
\hline $16-3,63-65$ & + & - & 2 & - & - & - & 3 & - & 23 & - & - & 26 & - & 16 & - & - & 31 & 0.2 \\
\hline & - & 2 & - & - & - & - & - & 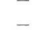 & - & - & 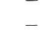 & - & - & 10 & - & - & 90 & 0.2 \\
\hline $16-6,38-41$ & 1 & + & - & - & - & - & 1 & + & 14 & - & - & - & - & 70 & - & 3 & 10 & 4.0 \\
\hline $16-6,47-50$ & + & - & - & - & + & - & 44 & - & 55 & - & - & - & - & - & - & - & - & - \\
\hline $16-6,124-126$ & - & + & - & - & - & - & 1 & + & 26 & - & - & - & - & 28 & 1 & - & 47 & - \\
\hline 1 & - & + & - & - & - & - & $\begin{array}{l}1 \\
4\end{array}$ & 2 & 28 & - & 1 & - & - & 1 & - & - & & - \\
\hline 1 & + & - & - & - & - & - & 19 & - & 4 & - & - & - & - & 2 & - & - & & - \\
\hline $17-3,30-35$ & - & 1 & - & - & - & - & 4 & 6 & 21 & - & - & - & - & 8 & - & - & 59 & - \\
\hline & - & 2 & - & - & - & - & 4 & 6 & 1 & - & - & - & - & 21 & - & - & 66 & - \\
\hline 3 & - & - & - & - & - & - & 33 & - & 24 & - & - & - & - & 8 & - & - & 6 & - \\
\hline 1 & 1 & 1 & - & - & - & 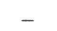 & - & + & 3 & - & - & - & - & . & - & - & & 1.5 \\
\hline 6,5 & $\begin{array}{l}1 \\
+\end{array}$ & ${ }_{-}^{1}$ & - & - & - & - & 4 & - & 30 & - & - & $\therefore$ & 23 & - & - & - & 3 & - \\
\hline-102 & 2 & 6 & - & - & - & 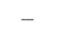 & - & 6 & 3 & - & - & - & - & - & 1 & - & 3 & 0.3 \\
\hline & - & - & - & - & - & - & - & 1 & 4 & - & - & - & - & 12 & - & - & 3 & - \\
\hline i) & _- & - & - & - & - & - & - & _- & 2 & - & - & - & - & 38 & - & - & & - \\
\hline & - & - & - & - & - & 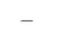 & - & - & 12 & - & - & - & - & - & - & - & & - \\
\hline $18-4,1$ & - & 1 & - & - & - & - & - & 3 & 2 & - & - & - & 19 & - & - & - & 75 & - \\
\hline 4,1 & - & + & - & - & - & - & - & 5 & 1 & - & - & - & 85 & - & - & - & 9 & - \\
\hline $19-2,9-$ & + & - & - & - & - & - & - & 1 & 16 & - & - & - & - & 56 & - & - & 28 & - \\
\hline & - & 1 & - & - & - & - & 5 & + & 11 & - & - & - & 9 & - & - & - & 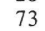 & - \\
\hline & - & + & - & - & - & - & 1 & 4 & 12 & - & - & - & - & - & - & - & 83 & - \\
\hline 2 & - & - & - &.. & - & - & - & + & 7 & - & - & - & - & 9 & - & - & 84 & - \\
\hline $20-5,78-80$ & - & - & - & - & - & _- & 1 & 1 & 48 & _- & - & - & - & - & 1 & - & 48 & - \\
\hline & + & 1 & - & - & - & - & 2 & $\begin{array}{l}1 \\
5\end{array}$ & $\begin{array}{r}40 \\
2\end{array}$ & - & & - & - & 4 & - & - & 5 & - \\
\hline & - & - & 1 & - & - & - & - & 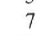 & 4 & - & - & - & - & 2 & + & - & & - \\
\hline $21-1,122$ & _- & - & - & - & - & - & - & 61 & 26 & - & - & - & - & - & - & - & 13 & - \\
\hline
\end{tabular}

Site 383

$$
\begin{array}{lllllllllllllllllll}
1-2,30-33 & 43 & 22 & - & - & - & - & - & + & - & + & - & - & - & 12 & - & - & 23 & 1.9 \\
1-2,140-144 & 48 & 19 & + & 1 & - & - & - & 1 & - & + & - & - & - & 14 & - & - & 18 & 2.5 \\
1-4,15-19 & 42 & 20 & - & + & - & - & - & + & - & + & - & - & - & 10 & - & - & 25 & 2.1
\end{array}
$$

Site 384

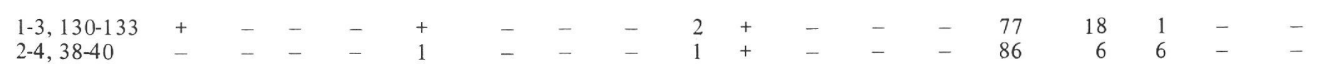

Site 385

\begin{tabular}{lrrlllllllllllllllll}
$1-1,102-104$ & 33 & 6 & + & - & - & - & - & 1 & - & 5 & - & - & - & 49 & - & - & 6 & 5.5 \\
$1-4,100$ & 50 & 14 & + & - & - & - & - & - & 6 & 2 & - & - & - & 1 & 2 & 6 & 19 & 3.6 \\
$2-2,31-33$ & 31 & 6 & - & - & - & - & - & + & - & + & - & - & - & 48 & 4 & 6 & 4 & 5.2 \\
$4-2,100$ & 2 & - & - & - & - & - & - & - & 2 & - & - & - & - & - & 94 & 2 & - & - \\
$5-2,100-112$ & 5 & + & + & - & - & - & - & - & - & + & - & - & - & 4 & 46 & 44 & - & 6.0 \\
$8-5,88$ & - & - & - & - & - & - & - & - & 96 & - & - & - & - & - & - & 4 & - & - \\
$9-1,94$ & + & - & - & - & - & - & - & - & 96 & - & - & - & - & + & 1 & 2 & - & - \\
$10-1,109-111$ & + & - & - & - & - & - & - & - & 96 & - & - & - & - & - & 3 & 1 & - & - \\
$11-1,120-123$ & + & - & - & - & + & - & - & - & 96 & - & - & - & - & - & - & 3 & - & - \\
$12-2,31-33$ & 2 & - & - & - & - & - & - & - & 85 & - & - & - & - & 6 & - & 7 & - & - \\
$13-3,84-87$ & 4 & - & - & - & - & - & - & - & 2 & 4 & 37 & - & - & 14 & - & 33 & 6 & - \\
$13-4,54-56$ & - & - & - & - & - & - & - & 1 & 7 & - & 26 & - & - & 31 & - & 32 & - & - \\
$14-1,68-72$ & 1 & - & - & - & - & - & - & - & 1 & - & - & - & 12 & 32 & + & 45 & 7 & - \\
$15-1,94-97$ & 2 & 1 & - & - & - & - & + & + & 4 & + & 12 & - & - & 10 & - & 13 & 57 & 1.7 \\
$15-3,77-80$ & - & - & - & - & - & - & - & + & 26 & + & 28 & - & - & 20 & - & 18 & 3 & - \\
$16-2,75$ & + & - & - & - & - & - & 18 & 10 & - & - & - & - & - & - & 3 & - & 69 & - \\
$16-2,94-96$ & 13 & 4 & 1 & - & - & - & 9 & - & + & - & - & - & - & 3 & - & - & 70 & 2.8 \\
$16-2,132-134$ & - & - & - & - & - & - & 12 & - & + & - & - & 12 & - & 6 & 1 & 2 & 66 & - \\
$16-2,137-140$ & 8 & 3 & - & - & - & 14 & 17 & - & 1 & - & - & - & - & + & - & - & 58 & 2.6 \\
$19-1,121-123$ & - & - & - & - & - & 21 & 78 & - & 1 & - & - & - & - & + & - & - & - & - \\
\hline
\end{tabular}


TABLE 2 - Continued

\begin{tabular}{|c|c|c|c|c|c|c|c|c|c|c|c|c|c|c|c|c|c|c|}
\hline $\begin{array}{c}\text { Sample } \\
\text { (Interval in } \mathrm{cm} \text { ) }\end{array}$ & $\mathrm{Qz}$ & Fs & $\mathrm{Pl}$ & Mc & V.a. & V.b. & Pal & $\mathrm{Ch} 1$ & $\mathrm{Ze}$ & $\mathrm{Gl}$ & Che & Gy & C.u. & C.o. & S.o. & P.o. & Un & $\begin{array}{l}\text { Qz } \\
\text { Fs }\end{array}$ \\
\hline \multicolumn{19}{|l|}{ Site 386} \\
\hline $1-3,74-76$ & 6 & - & _- & - & - & - & - & + & _- & - & - & - & _- & 93 & - & - & - & - \\
\hline $2-1,1$ & 43 & 9 & - & - & - & - & - & - & - & 1 & - & - & - & 19 & - & - & 28 & 4.8 \\
\hline $3-1,147-150$ & 31 & 10 & 1 & - & - & - & - & 6 & + & 1 & - & - & - & 15 & - & 10 & 25 & 2.7 \\
\hline $4-1,106$ & + & 2 & - & 1 & - & - & - & 18 & 1 & - & - & - & - & 57 & 1 & 5 & 16 & 0.2 \\
\hline $4-1,134-136$ & 2 & + & - & - & - & - & - & - & 97 & - & - & - & - & - & - & - & - & 6.0 \\
\hline $4-2,0-3$ & 11 & 3 & - & + & - & - & + & - & 2 & 1 & - & - & - & 2 & - & 6 & 74 & 4.0 \\
\hline $4-4,50$ & + & 4 & - & - & - & - & - & 8 & 11 & - & - & - & - & - & - & 17 & 59 & 0.1 \\
\hline $4-6,82$ & 2 & 8 & - & 2 & - & - & - & 22 & 4 & - & - & - & - & - & - & - & 61 & 0.3 \\
\hline $4-6,82-89$ & - & 3 & - & 3 & - & - & 1 & 28 & 6 & - & - & - & - & - & - & - & & - \\
\hline $5-1,60-62$ & - & - & - & - & - & - & 1 & 14 & 4 & - & - & - & - & 13 & - & - & 64 & - \\
\hline $5-2,6$ & 1 & 6 & - & - & - & - & - & 9 & 3 & - & - & - & - & 48 & 2 & 5 & 26 & 0.2 \\
\hline $5-2,33-35$ & - & - & - & _- & - & - & 1 & 17 & 11 & _- & - & _- & - & 22 & _- & - & 48 & - \\
\hline $5-2,90-92$ & - & - & - & + & - & - & - & 21 & 3 & + & - & - & - & 30 & - & - & 46 & - \\
\hline $5-2,102$ & + & 1 & - & - & - & - & - & 18 & 12 & - & - & - & - & 23 & 2 & - & 4 & - \\
\hline $5-2,105-107$ & - & - & - & - & - & - & - & 15 & 14 & - & 1 & - & - & 19 & 1 & - & 50 & - \\
\hline $5-4,120-122$ & - & - & - & - & - & - & 1 & 20 & 3 & - & - & - & - & 21 & - & - & 55 & - \\
\hline $6-1,99$ & - & 2 & - & - & - & - & - & 18 & 3 & - & - & - & - & 17 & + & - & 59 & - \\
\hline $6-1,104-106$ & - & - & - & 8 & - & - & - & 12 & 8 & - & - & - & - & 15 & + & - & 56 & - \\
\hline $7-2,54-58$ & + & + & - & - & - & - & - & 11 & 8 & - & - & - & - & 8 & + & - & 72 & - \\
\hline $7-4,139$ & - & - & - & - & - & - & 25 & 25 & 9 & - & - & - & - & 10 & 1 & - & 54 & - \\
\hline $8-5,1$ & - & - & - & - & - & - & + & - & 4 & - & - & - & - & 18 & + & - & 67 & - \\
\hline $9-2,7$ & - & 1 & - & 1 & 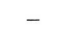 & - & 8 & - & 5 & - & - & - & - & 22 & 1 & - & 62 & - \\
\hline $12-1,57-59$ & 2 & + & + & - & - & - & - & 16 & 4 & - & - & - & - & 42 & - & 1 & 34 & 2.0 \\
\hline $12-2,69$ & - & 1 & - & + & . & - & - & 31 & 6 & - & - & - & - & 13 & 1 & - & 48 & \\
\hline $15-1,0-2$ & 7 & 1 & - & - & 1 & - & - & 11 & 13 & _- & - & - & 1 & - & 2 & - & 63 & 5.7 \\
\hline $15-1,93-97$ & 2 & 1 & - & - & 1 & - & - & 4 & - & - & 88 & - & - & 4 & - & - & - & 2.3 \\
\hline $15-2,5$ & 2 & - & - & - & - & - & - & - & - & - & - & - & - & 10 & 88 & - & - & - \\
\hline $15-2,12-13$ & 9 & - & - & - & - & - & - & - & - & 4 & - & - & - & 32 & 55 & - & - & - \\
\hline $15-2,1$ & 13 & + & - & - & 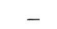 & - & - & - & - & 5 & - & - & - & 40 & 38 & 4 & - & _- \\
\hline $16-5,107$ & - & - & - & - & - & - & - & - & - & - & - & - & - & 7 & 92 & 1 & - & - \\
\hline $17-1,74$ & 4 & - & - & - & - & - & - & - & - & 1 & - & - & - & 13 & 82 & - & - & - \\
\hline $17-1,129$ & 8 & _- & - & - & 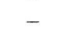 & - & - & - & - & 1 & - & - & - & 36 & 56 & - & - & - \\
\hline $1,130-135$ & 16 & 1 & - & - & 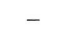 & - & - & - & - & 2 & - & - & - & 51 & 30 & - & - & 16.0 \\
\hline $17-2,82$ & + & - & - & - & - & - & - & - & - & - & - & - & - & 30 & 70 & - & - & - \\
\hline $17-4,63-66$ & 6 & 1 & - & - & - & - & - & + & - & 1 & - & - & - & 48 & 44 & - & - & 6.0 \\
\hline & 2 & - & - & - & - & - & - & + & 90 & 1 & - & - & - & - & 6 & 1 & - & \\
\hline $41-4,71-73$ & 8 & 3 & - & - & - & - & - & - & - & 1 & 4 & - & - & 50 & 19 & 15 & - & 2.7 \\
\hline
\end{tabular}

Site 387

\begin{tabular}{lllllllllllllllllll} 
1-2,118-120 & 6 & 1 & - & - & - & - & + & 3 & + & + & - & - & - & 35 & 33 & 7 & 13 & 6.0 \\
$2-5,10-12$ & 4 & 1 & - & + & - & - & + & 13 & - & - & - & - & - & 18 & 21 & 6 & 37 & - \\
$4-1,80-82$ & - & - & - & - & - & - & - & - & - & - & - & - & - & - & 94 & 6 & - & - \\
$6-3,49$ & - & - & - & - & - & - & - & - & - & - & - & - & - & - & 100 & - & - & - \\
$6, C C$ & 1 & + & - & - & - & - & - & - & - & - & - & - & - & - & 98 & 1 & - & - \\
$7-1,35-38$ & + & - & - & - & - & - & - & 11 & 4 & - & - & - & - & 18 & 26 & - & 10 & - \\
$7-1,100$ & + & - & - & - & - & - & - & - & - & - & - & - & - & 2 & 96 & 1 & - & - \\
$7-5,70$ & - & - & - & - & - & - & - & - & - & - & - & - & - & - & 99 & 1 & - & - \\
$7-1,70-74$ & 1 & - & - & - & + & - & - & 1 & - & 2 & - & - & - & - & 94 & 2 & - & - \\
$9-2,80$ & - & - & - & - & - & - & - & - & - & 1 & - & - & - & - & 98 & 1 & - & - \\
$9-3,117-120$ & - & - & - & - & - & - & - & - & - & - & - & - & - & 3 & 77 & 10 & 10 & - \\
$9-6,30$ & 12 & 3 & - & - & - & - & - & - & - & 8 & - & - & - & - & 74 & 3 & - & 4.0 \\
$10-5,77$ & + & + & 2 & + & - & - & - & - & - & 2 & - & - & - & 6 & 88 & 2 & - & - \\
$37-2,122$ & + & + & - & - & - & - & - & - & - & 1 & - & - & - & - & 83 & 10 & 6 & - \\
$44-1,130$ & + & 2 & - & - & - & - & + & - & 2 & 1 & 7 & - & 85 & - & 3 & - & - & - \\
\hline
\end{tabular}

Note: Qz - quartz; Fs - feldspar, refraction index less than 1.54 (potassium feldspar + acidic plagioclase); P1 - basic plagioclase; Mc - mica; V.a. - acidic volcanic glass; V.b. - basic volcanic glass; Pal. - palagonite; Ch1 - chlorite; Ze - zeolites; Gl - glauconite; Chc - chalcedony + cristobalite; Gy - gypsum; C.u. - carbonate unspecified; C.o. - organogenic carbonate; S.o. - organogenic silica; P.o. - organogenic phosphate; un. - unspecified, rock fragments and altered minerals. Where the sampled interval is marked by a single number, fraction $62-100 \mu \mathrm{m}$ was analyzed.

phosed) volcanogenic rocks. A more or less long time of post-eruptive alteration is presumed necessary to produce the observed mineral assemblages. The presence of pelagic components, such as calcareous microfossils and bone debris suggests possible edaphogeneous origin of the clastic minerals; that is, the submarine destruction of parent rocks and downslope gravity transport of the clastic material thus produced (Greek edaphos = bottom, base; Murdmaa, 1976).

3) Pelagic assemblages, in which both terrigenous and volcanogenic constituents are rare, whereas biogenic particles (siliceous, calcareous, phosphatic) or authigenic minerals (zeolites, rhodochrosite, siderite, barite) predominate. These characterize the uppermost layers of the Upper Cretaceous sections at Sites 382 and 385, the Eocene siliceous and calcareous turbidites at Sites 386 and 387, the nannofossil oozes at Site 384, the pelagic clay at Sites 385 (Paleocene?) and 387 (Oligocene), and the Miocene zeolitic clay at Site 386 .

\section{REFERENCES}

Murdmaa, I. O., 1976. Edaphogeneous clastic sediments of the Recent ocean. In Paleontology and marine geology, XXV Session of the International Geol. Congr., Reports of the Soviet Geologists: Moscow (Publishing House "Nauka") (in Russian). 